\title{
CDISC SDTM Vaccines Findings About Test Code Terminology
}

National Cancer Institute

\section{Source}

National Cancer Institute. CDISC SDTM Vaccines Findings About Test Code Terminology. NCI Thesaurus. Code C142187.

Terminology associated with the vaccines findings about test code codelist of the Clinical Data Interchange Standards Consortium (CDISC) Study Data Tabulation Model (SDT M). 